\title{
Predator-prey interactions in a bioinvasion scenario: differential predation by native predators on two exotic rocky intertidal bivalves
}

\author{
M. Soledad López ${ }^{1,2, *}$, Ricardo Coutinho ${ }^{1,2}$, Carlos E. L. Ferreira ${ }^{3}$, Gil Rilov ${ }^{4,5}$ \\ ${ }^{1}$ Divisão de Bioincrustação, Departamento de Oceanografia, Instituto de Estudos do Mar Almirante Paulo Moreira, \\ Marinha do Brasil, Rua Kioto 253, Praia dos Anjos, Arraial do Cabo, RJ, Brazil \\ ${ }^{2}$ Programa de Pós-graduação em Ecologia/Universidade Federal do Rio de Janeiro, Av. Brigadeiro Trompowsky, s/no, \\ Ilha do Fundão, RJ, Brazil \\ ${ }^{3}$ LECAR, Dept. de Biologia Marinha, Universidade Federal Fluminense, Campos do Valonguinho, Centro, Niterói, Brazil \\ ${ }^{4}$ Department of Zoology, Cordley 3029, Oregon State University, Corvallis, Oregon 97331-2914, USA \\ ${ }^{5}$ Present address: National Institute of Oceanography, Israel Oceanographic and Limnological Research, PO Box 8030,
} Haifa 31080, Israel

\begin{abstract}
The mechanisms determining the strength of interactions between non-indigenous and native species in the invaded environment are of great interest to both ecologists and managers. On a Brazilian rocky shore, we experimentally measured predation intensity and prey preference of native predators on 2 exotic bivalves, Perna perna (which has been present for centuries) and Isognomon bicolor (introduced ca. $20 \mathrm{yr}$ ago). Overall, predation was more intense on $P$. perna than on $I$. bicolor. Furthermore, P. perna was preyed upon more intensively by benthic crawling predators (whelks and, possibly, crabs), while larger, more mobile predators (fish and birds) were less selective. In addition, the larger, more abundant whelk Stramonita haemastoma selectively preyed on P. perna (for which handling time was shorter), while another whelk (Trachypollia nodulosa) preferred $I$. bicolor, although handling time was longer. Different shell morphologies of the 2 exotic prey and resource partitioning between the whelks may explain $S$. haemastoma and $T$. nodulosa feeding preferences, respectively. The thicker valves of $I$. bicolor compared to those of $P$. perna reduced the drilling or chipping efficiency by whelks. Although these prey species belong to the same functional group, differences in their shell characteristics could entail different mechanical constraints to predators. Therefore, native predators in the study system may prefer P. perna over I. bicolor because they are still adapting their foraging skills to handle the more recent invader, I. bicolor.
\end{abstract}

KEY WORDS: Exotic prey · Novel interactions $\cdot$ Predation intensity · Prey preference $\cdot$ Intertidal Subtropical rocky shores $\cdot$ Brazil

\section{INTRODUCTION}

The effect of consumers (herbivores and predators) on the structure of intertidal communities has been broadly studied along rocky shores (see Menge 2000 for review; Navarrete \& Castilla 2003, Rilov \& Schiel $2006 a, b)$. On rocky intertidal shores, the most abundant available prey are often mussels and/or barnacles, and the multiple species that prey on them can be separated into guilds according to their functional role (Sih et al. 1998). The regulating role of benthic predators with different mobility, such as whelks, crabs and sea stars, has been extensively studied (Paine 1966, Fairweather \& Underwood 1991, Menge et al. 1994, Navarrete \& Castilla 2003). Predators moving from adjacent habitats (land or subtidal), such as birds (e.g. Marsh 1986), lobsters (e.g. Robles et al. 1990) and fishes (e.g. Rilov \& Schiel 2006a,b), could also affect 
the structuring of benthic communities on rocky shores. Prey preference of these predators can be influenced by many factors such as prey size, energy content, handling time, availability and the past experience of the predator (Pyke et al. 1977, Hughes \& Dunkin 1984, Fairweather 1988, Etter 1996).

Multiple species have invaded many hard substrate habitats over time; therefore, native species have been exposed to different invaders for different periods of time (e.g. Wasson et al. 2005, Eastwood et al. 2007). A number of complex novel interactions could be established subsequent to invasion due to the arrangement of new native-exotic or exotic-exotic contact (Dudas et al. 2005, Grosholz 2005, Matern \& Brown 2005, MacDonald et al. 2007, Pratt \& Grason 2007). On the one hand, non-indigenous species are expected to lose some or all native co-evolved enemies. This enemyrelease hypothesis is one of many possible explanations for the success of invasive species in a new area (Colautti et al. 2004). On the other hand, non-indigenous species could find new enemies in invaded areas that could control their populations (Parker \& Hay 2005, Parker et al. 2006).

Invasive species can have important direct and/or indirect trophic effects on recipient communities as predators, prey or both (Rilov 2009). Recent studies have indicated a potential biotic resistance to bioinvasions through intensive consumption by native predators, mainly generalists, of the exotic species (Reusch 1998, deRivera et al. 2005, Parker \& Hay 2005). Native predators could easily incorporate (or even prefer) the newcomers in their diet if they do not need to change their predation techniques (e.g. Rilov et al. 2002). However, when local predators face new potential prey that is more difficult to handle, exposure time to the newcomer may be required for the prey to become an important part of their diet. Furthermore, different native predator species could show different responses in accordance with their abilities to recognize and handle the novel exotic prey. In the present study, we compared predation rates and feeding preferences of native predators on 2 exotic bivalves, Perna perna and Isognomon bicolor, in a subtropical rocky intertidal system on the southeastern Brazilian coast.

Comparisons of archaeological records with current community patterns on Brazilian rocky shores strongly suggest that this system has changed in the second half of the last millennium due to biological invasion. On southeastern Brazilian coasts, the low intertidal zones were probably occupied by the pearl oyster Pinctada imbricata until several hundred years ago, when this species was replaced by the African intertidal brown mussel Perna perna L. (Souza et al. 2003). Souza et al. (2003) proposed that $P$. perna arrival on Brazilian shores coincided with the slave trade from Africa in the 1500s. Nowadays, $P$. imbricata is relatively rare on rocky shores in southeastern Brazil, and $P$. perna is dominant at most sites (Souza et al. 2003, López 2008). The barnacle Tetraclita stalactifera dominated the mid-intertidal zone until recently, but during the 1990s a new invader, the Caribbean purse oyster Isognomon bicolor (Isognomonidae), showed up on the southern and central Brazilian coasts (Domaneschi \& Martins 2002). This new bivalve has dominated this zone with extensive populations which, at some sites, also extend to the low intertidal zone (López 2008).

Although field observations have documented Perna perna and Isognomon bicolor consumption by the whelk Stramonita haemastoma (López 2003), no studies have experimentally evaluated the intensity of predation on the 2 exotic prey. Both exotic bivalves have overlapping distributions, attach to the substratum with byssus threads and create beds, rendering them members of the same functional group. Nevertheless, they have distinctive shell shapes that may challenge local predators differently, and preliminary observations have suggested that $I$. bicolor shells are thicker, mainly in areas of the shell that protect the soft body.

In the present study we tested the hypothesis that native predators will prefer and prey more intensively upon Perna perna than Isognomon bicolor because of different shell morphologies that result in different predation efficiency (expressed in handling time). We compared the intensity of predation by different guilds of predators on P. perna and I. bicolor in the field. In the laboratory, we tested feeding preferences of the 2 most numerically abundant benthic predators, the whelks Stramonita haemastoma and Trachypollia nodulosa (Magalhães \& Coutinho 1995), on the 2 bivalve species. We experimentally tested past feeding experience (ingestion conditioning) of predators by exposing the bigger and more abundant whelk, $S$. haemastoma, collected from sites with low and high $I$. bicolor abundances, to the 2 non-indigenous species. Also, we contrasted these data with whelk prey selection observed in the field at the same 2 sites. Additionally, we compared the caloric value and shell thickness of the 2 prey species, as these could influence energy intake and whelk predation patterns (Burrows \& Hughes 1991, Morton et al. 2007).

\section{MATERIALS AND METHODS}

Study area. The study was conducted at the Cabo Frio upwelling tropical region on the southeastern Brazilian coast $\left(22^{\circ} 44^{\prime} \mathrm{S}, 42^{\circ} 00^{\prime} \mathrm{W}\right)$ (Fig. 1). The region is also considered a transition zone, being the northern and southern limit of temperate and tropical species, respectively (Palacio 1982, Guimarães \& Coutinho 


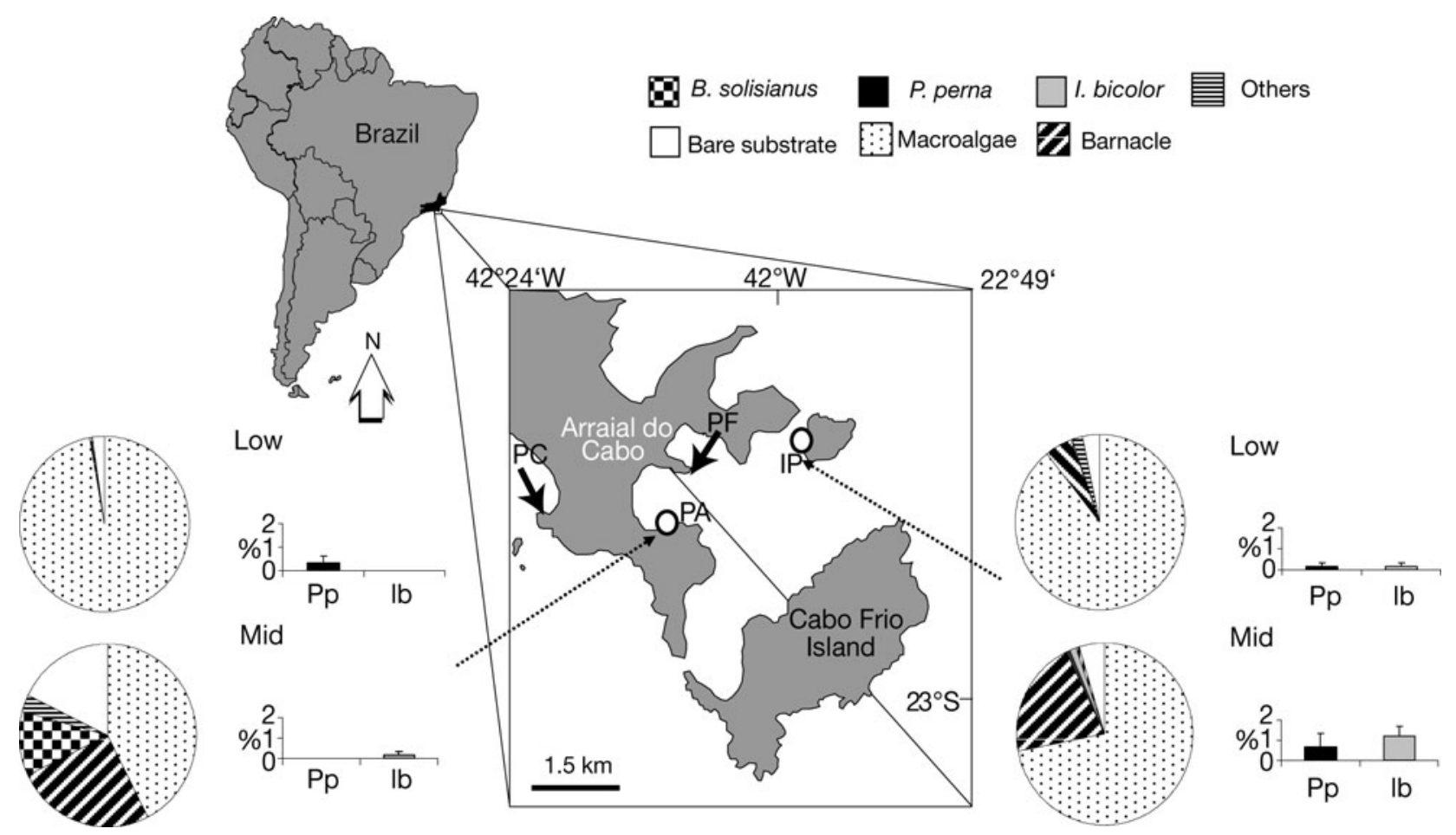

Fig. 1. Study area and selected sites at the Cabo Frio upwelling tropical region on the southeastern Brazilian coast. Circles indicate the predation intensity experiment sites, Praia dos Anjos (PA) and Ilha dos Porcos (IP). Mean percentage cover of sessile organisms and bare substrate in the low and mid intertidal zones at these 2 sites are also shown. Bivalves are shown by species, and other dominant organisms were pooled by taxonomic group. 'Others' include invertebrates such as gastropods, sea urchins, anemones and limpets. Due to low coverage $(<1 \%)$ of Perna perna (Pp) and Isognomon bicolor $(\mathrm{Ib})$, the data $(\mathrm{mean}+\mathrm{SE} ; \mathrm{n}=20)$ are shown in bar graphs with a small scale. Short arrows indicate the 2 sites with different coverage of Isognomon bicolor, Ponta da Fortaleza (PF; high cover) and Ponta da Cabeça (PC; low cover)

1996). Local geomorphology is generally characterized by relatively steep intertidal rocks, with a tidal range of approximately $1.4 \mathrm{~m}$. Predation intensity experiments were performed at 2 sites, Ilha dos Porcos (IP, $22^{\circ} 57^{\prime} \mathrm{S}, 41^{\circ} 59^{\prime} \mathrm{W}$ ) and Praia dos Anjos (PA, $22^{\circ} 58^{\prime} \mathrm{S}$, $42^{\circ} 01^{\prime} \mathrm{W}$ ). These sites are in a bay, but because of IP's position in relation to the prevailing NE winds, this site is slightly less exposed to wave action than PA. In order to study feeding habits of Stramonita haemastoma at sites with different prey availability, and to test the influence of past exposure to prey, we conducted field observations and collected the animals for laboratory trials at 2 exposed rocky shores, Ponta da Cabeça (PC, $22^{\circ} 59^{\prime} \mathrm{S}, 42^{\circ} 03^{\prime} \mathrm{W}$ ) and Ponta da Fortaleza (PF, $\left.22^{\circ} 58^{\prime} \mathrm{S}, 42^{\circ} 00^{\prime} \mathrm{W}\right)$. These sites present, respectively, low and high Isognomon bicolor abundances, but both have high Perna perna coverage. We selected different sites (PC and PF) to perform the field feeding observations because of the low abundances of the 2 prey species at IP and PA (see 'Results').

Study species. The 2 exotic bivalves belong to different families and thus have some distinctive morphological traits (see Fig. S1 in the supplement at www.int-res.com/articles/suppl/m403p101_app.pdf. The shape of Perna perna shells is elongated and regular, and the body's soft mass occupies the entire gap between the 2 valves. The shell of Isognomon bicolor is irregular in shape with valves that are positioned flat against each other at the posterior end, and a pearly nacreous internal region where the soft body is sheltered. P. perna can grow to $10 \mathrm{~cm}$, but mostly subtidally, while $I$. bicolor reaches $4.5 \mathrm{~cm}$. Despite these morphological differences, the 2 species belong to the same functional group, as both are sessile suspension feeders, attach themselves to the substrate by byssus threads, can form extensive beds and share a similar habitat (the lowest levels on intertidal rocky shores).

Field surveys. Sessile intertidal community characterization: To describe the ecological context (intertidal community structure) of the system where the 2 exotic bivalves occur, in October 2007 we estimated the percent cover of the dominant organisms and bare substrate using twenty $20 \times 20 \mathrm{~cm}$ quadrats placed haphazardly along $35 \mathrm{~m}$ at the low and mid-intertidal zones (henceforth low and mid zones) where the 2 species are usually found. Cover was assessed using the point-contact technique (30 random intersections within a 100-point grid), similar to Foster et al. (1991).

Predation intensity experiments: The experimental units were composed of 20 juvenile (5 to $15 \mathrm{~mm}$ shell length) Perna perna or Isognomon bicolor that were glued using epoxy glue (MEP 301 Tubolit $^{\circledR}$ ) to $5 \times 5 \mathrm{~cm}$ 
plastic tiles (sensu Rilov \& Schiel 2006a,b). To allow the valves to gape and feed, the bivalves were attached such that only the base of the anterior end of 1 valve was glued to the tile. At each site, 5 plots were placed in the low zone along $35 \mathrm{~m}$ of shoreline with the following treatments within each plot: (1) all predators (fully exposed); (2) whelk and crab exclusion (fence); (3) fish and bird exclusion (roof); and (4) full predator exclusion (fence + roof; see cage design in Rilov \& Schiel 2006b). One tile of each species was assigned to each treatment replicate. The experiment began on 17 and 18 April 2007 at PA and IP, respectively. Prey survivorship was monitored for 59 and $60 \mathrm{~d}$ at PA and PI, respectively with 5 monitoring dates in the first month and 2 in the second.

Predator densities: Estimations of benthic predator densities were obtained by counting individuals inside a $3 \mathrm{~m}^{2}$ area around each experimental plot $(\mathrm{n}=5)$ at IP and PA. Densities were measured 3 times at each site at low tide during the experiment duration. To quantify fish that were potential bivalve predators, we counted fish during high tide using a replicated visual census method by snorkeling along $40 \mathrm{~m}$ transects laid over the intertidal rocks at each site where the experiments were carried out. Censuses were confined to a depth of 0 to $3 \mathrm{~m}$ and were performed by C. E. L. F, who has considerable experience with this method and with the local fish fauna (Ferreira et al. 2001, 2004).

Prey selection by the whelk Stramonita haemastoma: We examined the variability of $S$. haemastoma foraging activities at sites with different exotic prey availabilities to complement the observations in the lab feeding trials (see following section), where the 2 exotic prey were equally accessible to the whelks. With these field observations our goal was to achieve a more comprehensive understanding about predator feeding decisions in natural (unmanipulated) conditions. We estimated prey abundances from the percent cover data. Because our objective was to describe prey selection patterns of $S$. haemastoma, we present only the proportion of potential prey available to predators in these sites. We recorded the cover of different prey types consumed by $S$. haemastoma at the sites with low (PC) and high Isognomon bicolor (PF) availability. Direct feeding observations were conducted in the mid zone during July-August 2006 at low tide during calm sea conditions. On each sampling date, we counted all predators at each site for $45 \mathrm{~min}$, and for each predator that was feeding we identified the prey item.

Laboratory procedures. Feeding preference: We compared the proportion of consumed prey and handling time by the 2 muricid whelks Stramonita haemastoma and Trachypollia nodulosa on the 2 exotic bivalves under laboratory conditions. S. haemastoma individuals with a shell length of 20 to $26 \mathrm{~mm}$ and $T$. nodulosa with a shell length of 14 to $20 \mathrm{~mm}$ were collected from the low and/or mid zones. A single predator was placed in each aquarium $(\mathrm{n}=14)$ and exposed to one or both prey types for $6 \mathrm{~d}$ for $S$. haemastoma and $11 \mathrm{~d}$ for $T$. nodulosa. We conducted 2 trials for $S$. haemastoma (June-July 2006 and March-June 2007), using different individuals, and one trial for T. nodulosa (May-June 2007). Whelks were acclimated without feeding for 5 to $7 \mathrm{~d}$ in a $5 \mathrm{l}$ aquarium containing aerated seawater, and one-third of the water was replaced every $2 \mathrm{~d}$. We followed the experimental design proposed by Underwood \& Clarke (2005). Whelks were offered either a single prey type (hereafter Stage 1, 6 Perna perna or 6 Isognomon bicolor) or 2 prey types (hereafter Stage 2, 3 P. perna and 3 I. bicolor). Prey size ranged between 10 and $25 \mathrm{~mm}$, and consumed prey was replaced to maintain equal prey availability. Because of the lack of statistical difference between proportions of consumed prey in the 2 S. haemastoma experiments (PF: $\chi^{2}=0.1, \mathrm{df}=1, \mathrm{p}=$ 0.75 ; PC: $\chi^{2}=0.06, \mathrm{df}=1, \mathrm{p}=0.81$ ), data were pooled for further analyses.

Higher encounter rates with a type of prey could increase predator experience, resulting in greater handling efficiency (Rovero et al. 1999). Therefore, to understand if past field experience with prey affects the foraging behavior of Stramonita haemastoma, we compared feeding preferences and handling time of the 2 prey species by whelks with low (PC: $<2 \%$ coverage) and high Isognomon bicolor encounter rates (PF: $\sim 40 \%$ coverage). We assumed that whelks with low and high I. bicolor encounter rates had less and more experience with this prey, respectively. Both sites had Perna perna beds in the low zone (PC: 10 and $40 \%$; PF: 6 and $15 \%$ during winter and spring/summer, respectively; López 2008).

Prey characteristics: Caloric value of prey was estimated from biochemical components (protein, lipid, glucose and ash). Each component was multiplied by its caloric content (Crisp 1984). For biochemical analysis, individuals of the 2 prey species (10 to $30 \mathrm{~mm}$ shell length) were collected from PF during June-July 2006. Data are expressed in $\mathrm{kcal} \mathrm{g}^{-1}$ ash-free dry weight.

Additionally, shell thickness of the exotic prey species was measured in 3 shell regions (valve edge, center and umbo) of the left and right valves using a digital caliper (0.01 $\mathrm{mm}$ accuracy). For Isognomon bicolor, we measured the edge of the nacreous region because this is the effective limit of the shell cavity that protects the soft body.

Data analysis. A 3-way ANOVA was used to compare percent survival among treatments at the end of the predation intensity experiment, with species (fixed; 2 levels), treatment (fixed; 4 levels) and site (random; 2 levels) as factors. Percent survival data were arcsine square- 
root transformed to increase the homogeneity of variances. Two-way ANOVAs were individually performed for benthic predator and fish density comparisons between sites (random; 2 levels) and species (fixed; 5 levels for benthic predators and 6 levels for fishes). We tested prey selection by Stramonita haemastoma in the field by comparing the proportion of available prey at each site, $\mathrm{PC}$ and $\mathrm{PF}$, with the proportion of prey consumed by predators at those sites with the log-likelihood $G$-test. When it was statistically significant, we investigated the selection of each prey type utilized by S. haemastoma with simultaneous Bonferroni confidence intervals (BCI) (Byers \& Steinhorst 1984).

The $\chi^{2}$ test (Zar 1999) was used to assess: (1) laboratory feeding preferences, comparing the frequency of each species of prey consumed in Stage 1 (single prey type) versus Stage 2 (2 prey types) by predators from the 2 sites; and (2) the effect of predators' past field encounter rates (with the exotic prey Isognomon bicolor) on the proportion of prey consumed in the laboratory in Stage 1 by whelks collected from sites with high and low I. bicolor abundance. Differences in prey handling time, measured in feeding preference experiments, and in the caloric content of the 2 prey, were explored using the non-parametric Mann-Whitney $U$ test. Shell thickness of each shell region was compared between the 2 prey species with a Student's $t$-test.

\section{RESULTS}

\section{Field surveys}

Sessile intertidal community characterization

Macroalgae (foliose, crustose and articulate calcareous) were dominant at low and mid zones at both experimental sites, and at the mid zone, barnacles were second in dominance (Fig. 1). Perna perna and Isognomon bicolor had very low percent cover $(<1 \%)$ in both low and mid zones. Although not quantitatively detected by the method utilized, I. bicolor was present in small clumps under foliose macroalgae in the low zone at PA. Individuals of $P$. perna and $I$. bicolor were found mainly within barnacle Tetraclita stalactifera patches in the mid zone (M. S. López pers. obs.).

It should be noted that during September 2006 (prior to our field experiment and community assessment), Isognomon bicolor populations along the southeastern Brazilian coast and especially in the Cabo Frio region experienced a rapid and extensive mortality event from as yet undetermined causes. Cover of this species at some sites dropped sharply after the mortality event at 2 of our study sites (mean \pm SE, PA: from $66.58 \pm 4.16$ to $3.91 \pm 0.34 ; \mathrm{PF}$ : from $59.69 \pm 2.93$ to $5.14 \pm 1.49$;
López 2008), and there was little evidence of recruitment 1 yr after the mortality event. Perna perna can attain cover of 60 to $70 \%$ at the low-mid zone on exposed sites but have lower cover at more sheltered areas like our study sites (López 2008).

\section{Predation intensity experiments}

Bivalve survivorship was higher in the predator exclusion (fence + roof) than predator-exposed (fully exposed, roof only and fence only) treatments; an indication that mortality was driven by predation. A complex mortality pattern was observed (Fig. 2), with treatment and site affecting its intensity (for Days 28/30: Treatment $F_{3,64}=19.5, \mathrm{p}=0.018$ and Site $F_{1,64}=$ 11.8, p < 0.001). Mortality, especially of Isognomon bicolor, was considerably slower at PA. After 3 d, about $30 \%$ of both species survived on the fully-exposed tiles at IP, while at PA, $53 \%$ of live Perna perna and $83 \%$ of I. bicolor were still present on tiles on the fourth day. Although differences between species were almost statistically significant $\left(F_{1,64}=156.4, \mathrm{p}=0.051\right)$, mortality in both the roof and fence treatments was still higher for $P$. perna than for I. bicolor (Fig. 2). The general trends did not change much until the end of the experiment (Fig. 2).

\section{Predator densities}

At IP, 5 different benthic predators were observed (gastropods: Stramonita haemastoma, Trachypollia nodulosa, Pisania auritula and Leucozonia nasa; crabs: Eriphia gonagra), and at PA there were 3 (gastropods: S. haemastoma, T. nodulosa; crabs: E. gonagra). S. haemastoma was the most abundant benthic predator at both sites, and its density was 2-fold higher at PA $\left(\right.$ mean $\pm \mathrm{SE}: 11.0 \pm 0.92$ ind. $\left.\mathrm{m}^{-2}\right)$ than at IP $(6.0 \pm 1.0$ ind. $\mathrm{m}^{-2}$ ). T. nodulosa was the second most abundant species, and its density was 5-fold higher at IP (2.6 \pm 0.50 ind $\left.\mathrm{m}^{-2}\right)$ than PA $\left(0.5 \pm 0.08\right.$ ind. $\left.\mathrm{m}^{-2}\right)$. These differences resulted in a site $\times$ species interaction $\left(F_{4,20}=\right.$ 13.96, df $=4, \mathrm{p}<0.00001)$. The abundance of other predators was very low at the 2 sites $\left(<0.5\right.$ ind. $\left.\mathrm{m}^{-2}\right)$.

Six species of fish were detected during visual censuses at IP and PA, and their abundances did not differ between the 2 sites $\left(F_{1,20}=1.17, \mathrm{p}=0.29\right)$. Our results showed significant differences in abundances between species $\left(F_{4,20}=18.64, \mathrm{p}=0.007\right)$, with the filefish Stephanolepis hispidus (mean $\pm \mathrm{SD}: 8.4 \pm 4.8$ ind. $\mathrm{m}^{-1}$ ) and the seabream Diplodus argenteus $(3.3 \pm 2.4)$ being the most abundant. At the sizes observed at study sites $(8$ to $12 \mathrm{~cm}$ ) these species could be efficient invertivores. 


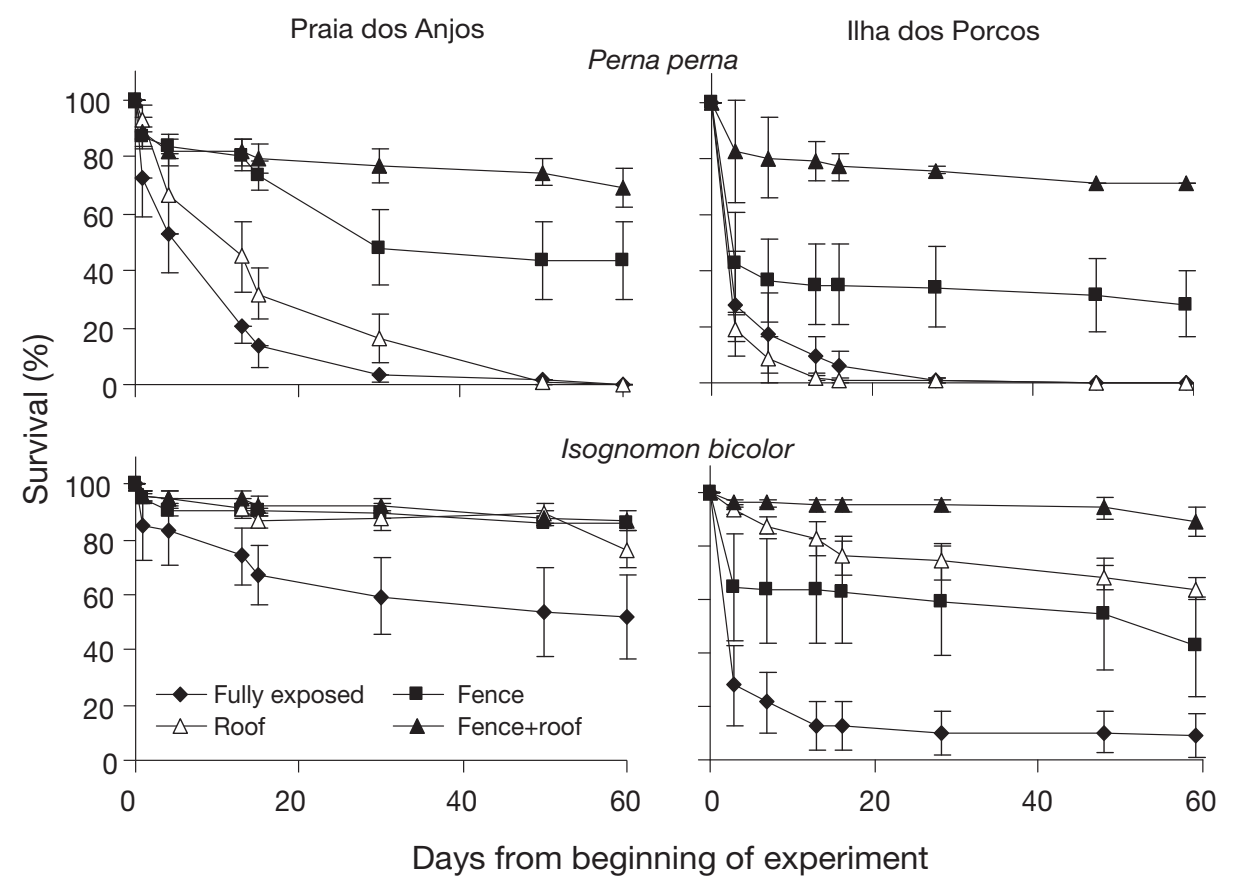

Fig. 2. Perna perna and Isognomon bicolor. Survival (mean $\pm \mathrm{SE}$ ) of the 2 exotic bivalves, $P$. perna and $I$. bicolor, under the different experimental treatments: exposed to all predators (fully exposed), fish/bird exclusion (roof), benthic predator exclusion (fence) and all large predator exclusion (fence + roof) at 2 sites on a Brazilian shore (April-June 2007)

Prey selection by Stramonita haemastoma

From a total of 328 and 217 predators quantified during 45 min of observation at PC and PF, only 15 and $24 \%$, respectively, were actively feeding. At PC, Stramonita haemastoma fed on 7 different prey types, whereas at PF, whelk diet was less diverse, with only 4 prey types. At PC, the site with low Isognomon bicolor cover, whelks fed more on Perna perna (47\%) than I. bicolor $(7 \%)$. In contrast, at $\mathrm{PF}$, the site with higher I. bicolor cover, whelks consumed more I. bicolor
(56\%) than P. perna (19\%). At the 2 sites, the proportion of available prey was different from the proportion of prey consumed by predators (PF: $G=192.81$, $\mathrm{df}=4$, $\mathrm{p}<0.05$; PC: $G=71.06, \mathrm{df}=5, \mathrm{p}<0.05)$. This pattern was mainly due to the positive selection of Megabalanus spp. and the negative selection of Tetraclita stalactifera at PF and the negative selection of T. stalactifera and Megabalanus spp. at PC (Table 1). The 2 exotic bivalves were consumed at proportions that fit their availability in the field without any evident pattern of selection (Table 1).

Table 1. Proportions of available (expected) and consumed (observed) prey, and the simultaneous Bonferroni confidence intervals (BCI) for different prey types of the native whelk Stramonita haemastoma on 2 intertidal rocky shores. Ponta da Cabeça had low and Ponta da Fortaleza had high Isognomon bicolor abundances. ND: not detected; OP: observed proportion

\begin{tabular}{|c|c|c|c|c|c|c|}
\hline \multirow[t]{2}{*}{ Prey } & \multicolumn{3}{|c|}{${ }_{-}$Ponta da Fortaleza } & \multirow[b]{2}{*}{$\begin{array}{l}\text { Expected } \\
\text { proportion }\end{array}$} & \multicolumn{2}{|c|}{ onta da Cabeça } \\
\hline & $\begin{array}{l}\text { Expected } \\
\text { proportion }\end{array}$ & $\begin{array}{c}\text { Observed } \\
\text { proportion }\end{array}$ & BCI & & $\begin{array}{c}\text { Observed } \\
\text { proportion }\end{array}$ & BCI \\
\hline \multicolumn{7}{|l|}{ Bivalves } \\
\hline Brachidontes solisianus & ND & 0 & & ND & 0.02 & $-0.04<$ OP $<0.08$ \\
\hline Perna perna & 0.18 & 0.19 & $0.10<\mathrm{OP}<0.28$ & 0.31 & 0.48 & $0.29<$ OP $<0.69$ \\
\hline Isognomon bicolor & 0.61 & 0.56 & $0.44<\mathrm{OP}<0.67$ & 0.03 & 0.06 & $-0.03<\mathrm{OP}<0.16$ \\
\hline \multicolumn{7}{|l|}{ Barnacles } \\
\hline Megabalanus spp. & 0.06 & 0.23 & $0.13<\mathrm{OP}<0.33$ & 0.13 & 0.04 & $-0.03<\mathrm{OP}<0.13$ \\
\hline Tetraclita stalactifera & 0.15 & 0 & & 0.39 & 0.11 & $-0.01<\mathrm{OP}<0.23$ \\
\hline \multicolumn{7}{|l|}{ Polychaetes } \\
\hline Phragmatopoma sp. & 0 & 0 & & 0.12 & 0.27 & $0.09<\mathrm{OP}<0.44$ \\
\hline Vermitid gastropods & 0.002 & 0.02 & $-0.01<\mathrm{OP}<0.05$ & ND & 0 & \\
\hline
\end{tabular}


Table 2. Total number of consumed prey and average handling time $(\mathrm{HT})$ in hours $( \pm \mathrm{SE})$ in laboratory feeding experiments (Stage 1: single prey type; Stage 2: mixed prey) by native whelks Stramonita haemastoma, with differential past field encounter rates with the exotic prey Isognomon bicolor (whelks collected from sites with high and low I. bicolor abundance and thus high and low prey encounter rates), and Trachypollia nodulosa. n: number of active predators that manipulated and consumed prey in each trial

\begin{tabular}{|c|c|c|c|c|c|c|c|c|c|c|c|c|}
\hline \multirow[t]{3}{*}{ Prey } & \multicolumn{8}{|c|}{$\longrightarrow$ S. haemastoma } & \multicolumn{4}{|c|}{$\longrightarrow$ T. nodulosa } \\
\hline & \multicolumn{4}{|c|}{ High $I$. bicolor encounter rates } & \multicolumn{4}{|c|}{ Low $I$. bicolor encounter rates } & \multirow[b]{2}{*}{ Stage 1} & \multirow[b]{2}{*}{ Stage 2} & \multirow[b]{2}{*}{ HT } & \multirow[b]{2}{*}{$\mathrm{n}$} \\
\hline & Stage 1 & Stage 2 & HT & $\mathrm{n}$ & Stage 1 & Stage 2 & HT & $\mathrm{n}$ & & & & \\
\hline P. perna & 43 & 92 & $7.28 \pm 2.05$ & 6 & 65 & 70 & $15.71 \pm 4.86$ & 7 & 9 & 1 & $27.00 \pm 3.55$ & 2 \\
\hline I. bicolor & 14 & 0 & $35.5 \pm 10.87$ & 3 & 30 & 0 & $36.87 \pm 16.08$ & 6 & 5 & 10 & $64.63 \pm 23.58$ & 4 \\
\hline
\end{tabular}

\section{Laboratory procedures}

Feeding preference

In the laboratory, Stramonita haemastoma with differential prior field encounter rates with Isognomon bicolor strongly preferred Perna perna over I. bicolor (PF: $\chi^{2}=$ 24.9, df =1, p < 0.0001; PC: $\chi^{2}=22.1, \mathrm{df}=1, \mathrm{p}<0.0001$; Table 2). Regardless of prior prey encounter rates (and probably different diet history), when the 2 prey species were simultaneously offered, $S$. haemastoma only consumed $P$. perna. When given no choice, proportions of prey eaten by predators from shores with low $I$. bicolor abundance were lower but statistically similar to predators from shores with high $I$. bicolor abundances $\left(\chi^{2}=\right.$ 0.54 , df $=1, \mathrm{p}=0.46$ ). Independent of prior encounter probability, handling time of $P$. perna appeared to be considerably shorter than that of $I$. bicolor (Table 2), but it was statistically significant only for predators with less I. bicolor encounter probability (shore with low I. bicolor abundance) (lower I. bicolor encounter rates: $U=1.0$, $\mathrm{n}_{1}=3, \mathrm{n}_{2}=6, \mathrm{p}=0.038$; higher $I$. bicolor encounter rates: $U=13, \mathrm{n}_{1}=6, \mathrm{n}_{2}=7, \mathrm{p}=0.25$ ) probably due to high variability among whelks from shores with high $I$. bicolor abundance. We also observed some failed predation events. After 12 to $48 \mathrm{~h}$ of handling, some I. bicolor individuals were abandoned by $S$. haemastoma without successful predation, evidenced by incomplete holes or chip signs in shells, and these prey items stayed alive for the rest of the experiment. This behaviour was observed 15 times for $I$. bicolor and twice for P. perna (failed events at 'individual prey stage').

The whelk Trachypollia nodulosa chose Isognomon bicolor over Perna perna $\left(\chi^{2}=5.7\right.$, $\mathrm{df}=1$, $\mathrm{p}=0.017$; Table 2). Handling time was longer on I. bicolor (33 to $120 \mathrm{~h}$ ) than on P. perna (12 to $48 \mathrm{~h})$, but the differences were not statistically significant ( $U=1.5, \mathrm{n}_{1}=2, \mathrm{n}_{2}=4, \mathrm{p}=0.19$ ). Also, this predator failed 6 times to feed on $I$. bicolor but there were no detected failure predation events on $P$. perna.
Prey characteristics

Mean caloric content in $\mathrm{kcal} \mathrm{g}^{-1}$ ash-free dry weight was similar for Perna perna (mean \pm SE: $4.48 \pm 0.13$, $\mathrm{n}=3$ ) and Isognomon bicolor $(4.53 \pm 0.28, \mathrm{n}=4 ; U=5$, $\mathrm{n}_{1}=3, \mathrm{n}_{2}=4, \mathrm{p}=0.72$ ). All regions of the shell were thicker in $I$. bicolor than in $P$. perna (valve edge: $t=$ 12.98, df $=58, \mathrm{p}<0.0001$; center: $t=5.94$, df $=54, \mathrm{p}<$ 0.0001; umbo: $t=6.83$, df $=58, \mathrm{p}<0.0001$; Fig. 3).

\section{DISCUSSION}

A growing body of research has compared consumption rates on native versus exotic prey species by native consumers in freshwater (Parker \& Hay 2005, Bollache et al. 2006), marine (Dudas et al. 2005, Pratt \& Grason 2007) and terrestrial (Agrawal \& Kotanen 2003) systems. The present study focused on an important but relatively little studied aspect of bioinvasions, the predation intensity by native predators on 2 exotic prey from the same functional group with differences in some shell characteristics. Our field and complementary laboratory experiments and observations con-

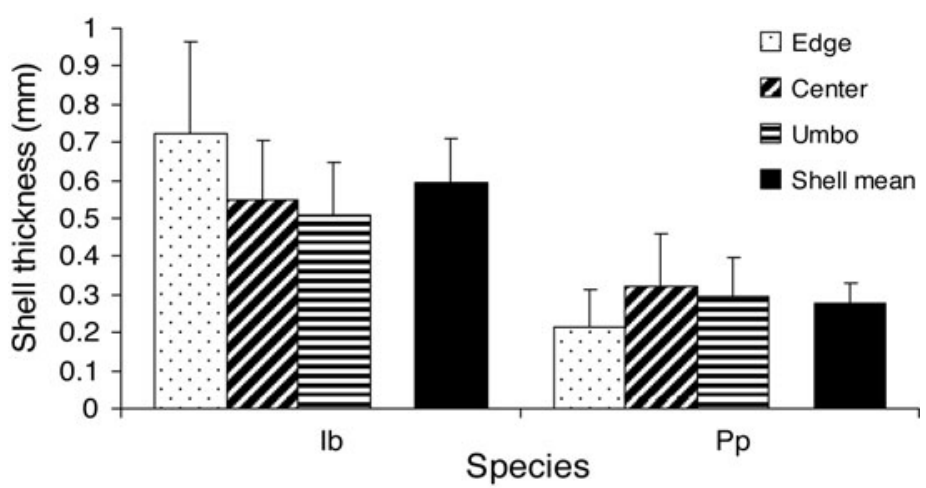

Fig. 3. Perna perna and Isognomon bicolor. Thickness (mean + SD) of 3 shell regions (valve edge, center and umbo) and mean shell thickness of all regions (black bars) of I. bicolor (Ib, shell length: 10 to $\left.29 \mathrm{~mm}_{i} \mathrm{n}=30\right)$ and $P$. perna $(\mathrm{Pp}$, shell length: 10 to $27 \mathrm{~mm} ; \mathrm{n}=30$ ) 
firmed most of our predictions regarding the intensity of these interactions and revealed some interesting and unexpected patterns.

\section{Exotic prey and native predator interactions}

Our field experiment showed that predation intensity by native predators (in all treatments) was higher on Perna perna than Isognomon bicolor. This result was consistent for both study sites, despite differences in the magnitude of predation. I. bicolor individuals that were protected by a roof from fish and/or bird predation suffered low mortality $(25 \%)$, while P. perna under a roof experienced $100 \%$ mortality. Many whelks (mostly Stramonita haemastoma) were indeed seen preying on $P$. perna and only a few (mostly Trachypollia nodulosa) were seen preying on I. bicolor. In contrast, inside fences, where predators had access from above but not from the sides, mortality rates were more similar between different prey species. This pattern suggests that benthic crawling predators (probably the most abundant whelk $S$. haemastoma) preferred preying on $P$. perna, whereas larger mobile predators were less selective than the whelk.

In the laboratory, we detected different responses of the 2 most abundant native benthic predators, the whelks Stramonita haemastoma and Trachypollia nodulosa, to the exotic prey. The 2 whelks consumed either of the 2 bivalves when only one species was offered as prey, but when the 2 prey species were simultaneously offered, $S$. haemastoma preferred Perna perna to Isognomon bicolor, whereas the smaller and less abundant $T$. nodulosa preferred $I$. bicolor. Also, during the field experiments, $S$. haemastoma individuals were more frequently seen preying on $P$. perna, with only few feeding events observed on $I$. bicolor. Conversely, T. nodulosa individuals preyed on I. bicolor but never on P. perna.

Prey preference exhibited by Stramonita haemastoma was in agreement with optimal foraging theory, as this whelk handled Perna perna (its preferred prey) faster than Isognomon bicolor. Conversely, Trachypollia nodulosa also spent more time handling I. bicolor, but still preferred it to $P$. perna. This intriguing result may reflect a case of resource partitioning between the 2 whelks, driven by optimal foraging decisions. $S$. haemastoma and P. perna are more abundant at waveexposed sites and thus frequently interact. T. nodulosa co-occurs with $S$. haemastoma in more wave-protected sites where $P$. perna is less abundant. Therefore, if $S$. haemastoma is a better competitor when preying on $P$. perna (the optimal prey), as suggested by the faster handling time, $T$. nodulosa may 'choose' to feed on $I$. bicolor (with equivalent caloric value to $P$. perna) at sites where this prey is abundant but less preyed on by $S$. haemastoma, resulting in reduced diet overlapping. Further experiments to analyze competitive interactions are needed to test this hypothesis.

Changes in prey abundances frequently result in feeding behaviour shifts (Fairweather 1988, Rilov et al. 2002) because they may modify encounter probability and consequently affect the predators' searching time. The proportion of Isognomon bicolor consumed by whelks in the field was greater at the site where $I$. bicolor availability was high. In spite of the strong preference observed in the laboratory for Perna perna, in the field Stramonita haemastoma was seen preying on the 2 exotic bivalves in proportions equivalent to their availability, thus showing no selection for either bivalve. These results indicate that higher encounter probabilities, even of the non-preferred I. bicolor, could affect the feeding pattern of these whelks with a possible functional response of predators to prey abundance variability. When the density of bivalve prey changes (in space or time), predators may show different functional responses (quantity of prey consumed by the predator related to prey density) with distinctive patterns of prey mortality (Seitz et al. 2001). The type of functional response of predators to temporal and spatial variation in the relative abundance of different prey can be important for prey persistence or local extinction. This topic deserves more detailed study with spatial and temporal replication.

We suggest that the difference in predation intensity and preference can be largely explained by the fact that the 2 prey species have different shell morphologies, since the 2 exotic bivalves have similar caloric value and when only their flesh was offered to whelks there was no prey preference (see below). The shell shape of Isognomon bicolor is different from that of Perna perna in that the former has thicker valves, mainly at the nacreous edge (Fig. S1 in the supplement), and the soft body is located only at the bottom of the shell. These distinct characteristics could reduce the efficiency of the drilling or chipping methods that are usually used by whelks to handle bivalves (Morton et al. 2007). In other regions, S. haemastoma have demonstrated high foraging plasticity by preferring a novel prey that had similar (invasive mussel; Rilov et al. 2002) or very different (Polychaeta; Watanabe \& Young 2006) morphological characteristics from its more common prey (mussels and barnacles in Israel and Florida, respectively). In our experiments Stramonita haemastoma chipped the shell of small P. perna $(<25 \mathrm{~mm})$, allowing the introduction of the proboscis and opening of the valves without the need to drill. Individuals that attempted to use the same technique by chipping the thinner prismatic shell extension failed to prey on I. bicolor, because they were unable to get to 
the soft body parts. In some cases, the predators abandoned the prey, while in others they chose to drill over the soft body region or near the byssus production region, thus increasing the overall handling time. Trachypollia nodulosa usually drilled I. bicolor, resulting in long handling times.

Regardless of feeding preference pattern, both whelks were less efficient when preying on Isognomon bicolor. Differences in morphological shell characteristics could represent different mechanical problems to predators (Hughes \& Dunkin 1984, Hughes \& O'Brien 2001); therefore, whelks in Brazil may still be adapting their foraging skills to more efficiently handle the more recently introduced I. bicolor. This may be supported by the lack of differences in handling efficiency of $I$. bicolor by Stramonita haemastoma with different past prey encounter rates (due to different prey abundances in the field). We expected that predators that had had a higher encounter probability because of higher abundances of $I$. bicolor would be more experienced and consequently more efficient in preying on this bivalve. However, there was no difference in handling time between predators with different past prey contact. Preliminary results from experiments in which we offered $S$. haemastoma only the flesh of the 2 bivalves showed that the whelk did not prefer one species to the other, suggesting that shell morphology rather than taste is the reason for preference.

Although the present study did not target potential differences in genotypic adaptations of native predators to prey on the exotic bivalves, we cannot ignore the fact that the 2 exotic bivalves have been exposed to native predators in the invaded area for different lengths of time, as Perna perna is a long-established species introduced centuries ago, whereas Isognomon bicolor was introduced more recently. The shorter contact time of the native benthic predators with $I$. bicolor may have resulted in a weaker adaptive response (expressed in longer prey handling time). Another possible explanation for the lower predation intensity on $I$. bicolor is prior contact between predator and prey in the native habitat resulting in anti-predator adaptation by this prey. The whelks Trachypollia nodulosa and Stramonita haemastoma have a Caribbean distribution and are thus sympatric with $I$. bicolor on some shores of their native distribution range (Florida; Camp et al. 1998). Moreover, I. bicolor has been reported as part of the diet of the 2 whelks (Ingham \& Zischke 1977). Thus I. bicolor may have developed anti-predator shell adaptations against whelk predation as a result of a long coevolutionary history in their native range of distribution. Edgell \& Rochette (2008) proposed a similar explanation for differential predation rates by the exotic predator Carcinus maenas on 2 prey with different anti-predation traits, the native (Littorina obtusata) and exotic (L. littorea) snails in the northwest Atlantic. C. maenas and L. littorea may have interacted in their native range of distribution so that $L$. littorea developed more crab-resistant shells and is therefore preyed on at lower rates than L. obtusata.

Although Perna perna is comparatively less armoured against predation than Isognomon bicolor, recent studies have shown that different mussels can exhibit anti-predator phenotypic responses induced by predator cues like increasing shell thickness (Caro \& Castilla 2004, Freeman \& Byers 2006), byssal production (Cheung et al. 2006, Caro et al. 2008) and clumping behavior (Nicastro et al. 2007). Future studies that address inducible anti-predator responses of the 2 exotic prey by different native predators will greatly increase our understanding of the mechanism responsible for the predator-prey interactions shown in the present study. At this stage, the most parsimonious explanation is that shell morphology is the primary proximate cause of the differential predation rates observed between the 2 exotic bivalves.

\section{Habitat-species interactions}

Although we did not explicitly test the effects of wave exposure on predation rates, we found that the intensity of predation was higher at the site slightly less exposed to wave action (IP). These results are in accord with the Menge-Sutherland environmental stress model (Menge et al. 1986). One of the model predictions is that predation, an important structuring force, will be more intense in more benign environments. This prediction has been supported by studies in some temperate rocky shores (e.g. Menge et al. 1986, Underwood et al. 1983). Also, Richardson \& Brown (1990) showed high wave exposure as a limiting factor in foraging activity by benthic predators. Thus the slight difference of wave action between the sites in the present study might be enough to reduce foraging activity and predation efficiency of benthic predators at PA. The difference in predation intensity between PA and IP was greater for Isognomon bicolor than for Perna perna. This may be related to an interaction between wave action and handling time for benthic predators and wave action and opportunity for predation for more mobile predators.

Another plausible explanation is the seascape hypothesis. On the temperate coasts of New Zealand, Rilov \& Schiel $(2006 \mathrm{a}, \mathrm{b})$ proposed a model where different guilds of predators could exert different effects on mussel recruits depending on the local seascape. There, fish preyed heavily on mussels in areas with adjacent subtidal reefs. In the present study, the predation rate on fenced tiles (that allow fish and bird pre- 
dation) was higher at IP for both exotic species. The 2 study sites had subtidal reefs; however, reefs at IP are deeper and thus have a larger area in which to sustain a comparatively more diverse and abundant reef fish fauna (C. E. L. Ferreira unpubl. data). These aspects can facilitate a seascape effect. Also, the slope in IP is more abrupt than in PA, which could also aid fish predators in their approach to shallow sessile prey, even though we did not detect differences in densities of dominant fishes between sites. Oystercatcher Haematopus sp. visits were also more frequent at IP throughout the experiment (M. S. López pers. obs.). Although oystercatchers were never observed preying on experimental tiles, bird predation cannot be ruled out; predation of some large Perna perna individuals was observed in nearby areas.

Although the bivalve coverage was low at the 2 sites during the present study, quantitative data on Isognomon bicolor distribution prior to the present study showed a high abundance of this species at PA, where it formed an extensive bed in the mid zone, whereas it had low abundance at IP (M. S. López \& R. Coutinho unpubl. data). The high regional mortality event of $I$. bicolor mentioned in 'Results: Sessile intertidal community characterization' diminished this difference. We propose that the difference in predation pressure observed during the present study could explain the difference in bivalve coverage among sites prior to the mortality event. Different larval supply could be an alternative or complementary explanation of the differences in bivalve coverage between the sites. Preliminary data indicated higher Perna perna and I. bicolor recruitment at PA than IP shores (M. S. López et al. unpubl. data).

In conclusion, the present study shows that: (1) predation intensity by native predators is generally stronger on Perna perna than on Isognomon bicolor; and (2) benthic predators preyed selectively on $P$. perna, while non-benthic predators were less selective and preyed on both exotic species. It is possible that because of the small prey sizes used in the present study, the differences in shell thickness between the 2 bivalve species had no effect on handling time by more mobile and larger predators that fed from above. Furthermore, in the laboratory, the 2 tested benthic predators (whelks) showed opposite prey preference patterns, supporting the idea of non-functional redundancy (and non-additive effect on prey) of similar predators within a guild (Griffen \& Byers 2006) and a potential resource partitioning. Based on our results, we propose that, although the studied exotic prey are similar in many morphological and ecological features, the differences in some shell characteristics (shape and thickness) may explain the low predation rates and low predation efficiency (high handling times) observed on
I. bicolor. These findings have important implications for our understanding of the structure and function of intertidal communities within the bioinvasion context.

Acknowledgements. Many thanks to the members of the Biofouling Lab at the Instituto de Estudos do Mar Almirante Paulo Moreira (IEAPM) that helped in the field and with lab work, especially F. Siviero, S. A. Coelho Souza, I. Cunha Ferreira, L. V. R. de Messano, E. Carino Fernandes. We thank S. Dudas and K. Heiman for comments and suggestions on an earlier version of this manuscript. Thanks to M. Nabethe of the Chemistry Laboratory (Department of Oceanography, IEAPM) for biochemical analyses of the bivalves. Comments from 4 anonymous reviewers greatly improved this manuscript. This study was supported by the Programa de Apoio a Núcleos de Excelência (PRONEX) from Fundação de Amparo a Pesquisa do Rio de Janeiro (FAPERJ). M.S.L was supported by a Coordenação de Aperfeiçoamento de Pessoal de Nivel Superior (CAPES) doctoral fellowship during the study. R.C. was supported by a grant from Conselho Nacional de Desenvolvimento Científico e Tecnológico (CNPq).

\section{LITERATURE CITED}

Agrawal AA, Kotanen PM (2003) Herbivores and the success of exotic plants: a phylogenetically controlled experiment. Ecol Lett 6:712-715

Bollache LC, Kaldonski N, Troussard JP, Lagrue C, Rigaud T (2006) Spines and behaviour as defences against fish predators in an invasive freshwater amphipod. Anim Behav 72:627-633

Burrows MT, Hughes RN (1991) Variation in foraging behaviour among individuals and populations of dogwhelks, Nucella lapillus: natural constraints on energy intake. J Anim Ecol 60:497-514

Byers CR, Steinhorst RK (1984) Clarification of a technique for analysis of utilization-availability data. J Wildl Manag 48: 1050-1053

Camp DK, Lyons WG, Perkins TH (1998) Checklists of selected shallow-water marine invertebrates of Florida. Florida Marine Research Institute Tech Rep TR-3. Florida Department of Environmental Protection, St. Petersburg, FL

Caro AU, Castilla JC (2004) Predator-inducible defences and local intrapopulation variability of the intertidal mussel Semimytilus algosus in central Chile. Mar Ecol Prog Ser 276:115-123

Caro AU, Escobar J, Bozinovic F, Navarrete SA, Castilla JC (2008) Phenotypic variability in byssus thread production of intertidal mussels induced by predators with different feeding strategies. Mar Ecol Prog Ser 372:127-134

> Cheung SG, Luk KC, Shin PKS (2006) Predator-labeling effect on bissus production in marine mussels Perna viridis (L.) and Brachidontes variabilis (Krauss). J Chem Ecol 32:1501-1512

> Colautti RI, Ricciardi A, Grigorovich IA, MacIsaac HJ (2004) Is invasion success explained by the enemy release hypothesis? Ecol Lett 7:721-733

Crisp DJ (1984) Energy flow measurements. In: Holme NA, McIntyre AD (eds) Methods for the study of marine benthos. Blackwell Scientific Publications, Melbourne

deRivera CE, Ruiz GM, Hines AH, Jivoff P (2005) Biotic resistance to invasion: native predator limits abundance and distribution of an introduced crab. Ecology 86:3364-3376 
Domaneschi O, Martins CM (2002) Isognomon bicolor (C.B. Adams) (Bivalvia, Isognomonidae): primeiro registro para o Brasil, redescrição da espécie e considerações sobre a ocorrência e distribuição de Isognomon na costa brasileira. Rev Bras Zool 19:611-627 (with English Abstract)

Dudas SE, McGaw IJ, Dower JF (2005) Selective crab predation on native and introduced bivalves in British Columbia. J Exp Mar Biol Ecol 325:8-17

Eastwood MM, Donahue MJ, Fowler AE (2007) Reconstructing past biological invasions: niche shifts in response to invasive predators and competitors. Biol Invasions 9: 397-407

Edgell TC, Rochette R (2008) Differential snail predation by an exotic crab and the geography of shell-claw covariance in the Northwest Atlantic. Evolution 62:1216-1228

Etter RJ (1996) The effect of wave action, prey type, and foraging time on growth of the predatory snail Nucella lapillus (L.). J Exp Mar Biol Ecol 196:341-356

Fairweather PG (1988) Experiments on the interaction between predation and the availability of different prey on rocky seashores. J Exp Mar Biol Ecol 114:261-273

Fairweather PG, Underwood AJ (1991) Experimental removals of a rocky intertidal predator: variations within two habitats in the effects on prey. J Exp Mar Biol Ecol 154:29-75

Ferreira CEL, Gonçalves JEA, Coutinho R (2001) Community structure of fishes and habitat complexity in a tropical rocky shore. Environ Biol Fishes 61:353-369

Ferreira CEL, Floeter SR, Gasparini JL, Ferreira BP, Joyeux JC (2004) Trophic structure patterns of Brazilian reef fishes: a latitudinal comparison. J Biogeogr 31:1093-1106

> Foster MS, Harrold C, Hardin DD (1991) Point vs. photo quadrat estimates of the cover of sessile marine organisms. J Exp Mar Biol Ecol 146:193-203

Freeman AS, Byers JE (2006) Divergent induced responses to an invasive predator in marine mussel populations. Science 313:831-833

Griffen BD, Byers JE (2006) Intraguild predation reduces redundancy of predator species in multiple predator assemblage. J Anim Ecol 75:959-966

> Grosholz ED (2005) Recent biological invasion may hasten invasional meltdown by accelerating historical introduction. Proc Natl Acad Sci USA 102:1088-1091

Guimarães MA, Coutinho R (1996) Spatial and temporal variation of benthic marine algae at the Cabo Frio upwelling region, Rio de Janeiro, Brazil. Aquat Bot 52:283-299

> Hughes RN, Dunkin SB (1984) Behavioral components of prey selection by dogwhelks, Nucella lapillus (L.), feeding on mussels, Mytilus edulis L., in the laboratory. J Exp Mar Biol Ecol 77:45-68

Hughes RN, O'Brien N (2001) Shore crabs are able to transfer learned handling skills to novel prey. Anim Behav 61: 711-714

Ingham RE, Zischke JA (1977) Prey preferences of carnivorous intertidal snails in the Florida Keys. Veliger 20:49-51

López MS (2003) Efecto de la potencial presa exótica Isognomon bicolor (Adams, 1845) sobre la ecología trófica de Stramonita haemastoma (Kool, 1987) en el intermareal rocoso de Arraial do Cabo, RJ, Brasil. MS thesis, Universidad Internacional de Andalucía Sede Antonio Machado de Baeza, Jaén

López MS (2008) O bivalve invasor Isognomon bicolor e seu papel nas comunidades de entremarés rochoso na região de ressurgência de Cabo Frio, RJ. PhD thesis, Universidade Federal do Rio de Janeiro, RJ, Brasil

> MacDonald JA, Roudez R, Glover T, Weis JS (2007) The invasive green crab and Japanese shore crab: behavioral inter- actions with a native crab species, the blue crab. Biol Invasions 9:837-848

Magalhães CA, Coutinho R (1995) Distribution and zonation of three species of predatory gastropods: patterns and adaptations to wave impact in the rocky shore. Publ Espec Inst Oceanogr 11:123-131

Marsh CP (1986) Rocky intertidal community organization: the impact of avian predators on mussel recruitment. Ecology 67:771-786

Matern SA, Brown LR (2005) Invaders eating invaders: exploitation of novel alien prey by the alien shimofuri goby in the San Francisco Estuary, California. Biol Invasions 7:497-507

> Menge BA (2000) Top-down and bottom-up community regulation in marine rocky intertidal habitats. J Exp Mar Biol Ecol 250:257-289

Menge BA, Lubchenco J, Gaines SD, Ashkenas LR (1986) A test of the Menge-Sutherland model of community organization in a tropical rocky intertidal food web. Oecologia 71:75-89

> Menge BA, Berlow EL, Blanchette CA, Navarrete SA, Yamada SB (1994) The keystone species concept: variation in interaction strength in a rocky intertidal habitat. Ecol Monogr 64:249-286

> Morton B, Peharda M, Harper EM (2007) Drilling and chipping patterns of bivalve prey shell penetration by Hexaplex trunculus (Mollusca: Gastropoda: Muricidae). J Mar Biol Assoc UK 87:933-940

> Navarrete SA, Castilla JC (2003) Experimental determination of predation intensity in an intertidal predator guild: dominant versus subordinate prey. Oikos 100:251-262

> Nicastro KR, Zardi GI, McQuaid CD (2007) Behavioural response of invasive Mytilus galloprovincialis and indigenous Perna perna mussels exposed to risk of predation. Mar Ecol Prog Ser 336:169-175

> Paine RT (1966) Food web complexity and species diversity. Am Nat 100:65-75

Palacio FJ (1982) Revisión zoogeográfica marina del sur del Brasil. Bol Inst Oceanogr (Sao Paulo) 31:69-92

> Parker JD, Hay ME (2005) Biotic resistance to plant invasions? Native herbivores prefer non-native plants. Ecol Lett 8: 959-967

> Parker JD, Burkepile DE, Hay ME (2006) Opposing effects of native and exotic herbivores on plant invasion. Science 311:1459-1461

> Pratt CM, Grason EW (2007) Invasive species as a new resource: Does a nudibranch predator prefer eating an invasive bryozoan? Biol Invasions 9:645-655

Pyke GH, Pulliam HR, Charnov EL (1977) Optimal foraging: a selective review of theory and tests. Q Rev Biol 52: 137-154

> Reusch TBH (1998) Native predators contribute to invasion resistance to the non-indigenous bivalve Musculita senhousia in southern California, USA. Mar Ecol Prog Ser 170:159-168

Richardson TD, Brown KM (1990) Wave exposure and prey size selection in an intertidal predator. J Exp Mar Biol Ecol 142:105-120

Rilov G (2009) Predator-prey interactions in marine bioinvasions. In: Rilov G, Crooks JA (eds) Marine biological invasions in marine ecosystems: ecological, management, and geographic perspectives. Springer, Heidelberg, p 261-285

Rilov G, Schiel DR (2006a) Seascape-dependent subtidalintertidal trophic linkages. Ecology 87:731-744

Rilov G, Schiel DR (2006b) Trophic linkages across seascapes: subtidal predators limit effective mussel recruitment in rocky intertidal communities. Mar Ecol Prog Ser 327:83-93 
Rilov G, Gasith A, Benayahu Y (2002) Effect of an exotic prey on the feeding pattern of a predatory snail. Mar Environ Res 54:85-98

Robles CD, Sweetnam DA, Eminike J (1990) Lobster predation on mussels: shore-level differences in prey vulnerability and predator preference. Ecology 71:1564-1577

Rovero F, Hughes RN, Chelazzi G (1999) Effect of experience on predatory efficiency of dogwhelks. Anim Behav 57: 1241-1249

Seitz RD, Lipcius RN, Hines AN, Eggleston DB (2001) Density-dependent predation, habitat variation, and the persistence of marine bivalve prey. Ecology 82:2435-2452

Sih A, Englund G, Wooster D (1998) Emergent impacts of multiple predators on prey. Trends Ecol Evol 13:350-355

Souza RCCL, Fernandes FC, Silva EPA (2003) A study on the occurrence of the brown mussel Perna perna on the sambaquis of the Brazilian coast. Rev Mus Arqueol Etnol Sao Paulo 13:3-24

Editorial responsibility: Matthias Seaman, Oldendorf/Luhe, Germany
Underwood AJ, Clarke KR (2005) Solving some statistical problems in analyses of experiments on choices of food and on associations with habitats. J Exp Mar Biol Ecol 318: $227-237$

Underwood AJ, Denley EJ, Moran MJ (1983) Experimental analyses of the structure and dynamics of mid-shore rocky intertidal communities in New South Wales. Oecologia 56: 202-219

> Wasson K, Fenn K, Pearse JS (2005) Habitat differences in marine invasions of central California. Biol Invasions 7: 935-948

- Watanabe JT, Young CM (2006) Feeding habits and phenotypic changes in proboscis length in the southern oyster drill, Stramonita haemastoma (Gastropoda: Muricidae), on Florida sabellariid worm reefs. Mar Biol 148: 1021-1029

Zar JH (1999) Biostatistical analysis. Prentice Hall, Upper Saddle River, NJ

Submitted: May 2, 2009; Accepted: November 9, 2009 Proofs received from author(s): March 2, 2010 